\title{
Развитие современной грамматической парадигмы: еще один важный шаг
}

(Рецензия на книгу: Грамматика речевых действий в медиалингвистике / Л.Р. Дускаева, В.И. Коньков, Т.Ю. Редькина / под ред. Л.Р. Дускаевой. М.: ФЛИНТА, 2019. Серия «Язык в координатах массмедиа»)

Чжан Хуэйцинь

@ Чжан Хуэйцинь доктор филологических наук, профессор, декан факультета русского языка Второго Пекинского университета иностранных языков (г. Пекин, Китай), stilistika204@yandex.ru
В современном обществе количество речедеятелей, вовлекаемых в процессы медиатизации реальности, увеличивается лавинообразно. Этому, в частности, способствуют те вызовы, с которыми сталкивается современная цивилизация, например пандемия коронавируса, вследствие которой онлайн-занятия стали основной формой взаимодействия обучающих и обучаемых. Рост общественных потребностей в знаниях о речевом воздействии на массовую аудиторию, о котором говорится в «Предисловии" к основному тексту монографии (с. 91), можно считать главной причиной появления рецензируемой книги, предназначенной всем, кто интересуется языком массмедиа.

Широтой целевой аудитории «Грамматики речевых действий в медиалингвистике» обусловлено то, что книга, объектом представления в которой выступает грамматическое устройство медиатекста, содержит также краткий очерк истории и концепции медиалингвистики как научной дисциплины в целом, куда, наряду с грамматикой медиаречи, входит также критика медиаречи, медиастилистика и медиадискурсология. Следует отметить, что представленное понимание структуры медиалингвистики как четырехчастного конструкта ранее было предложено в словаре-справочнике «Медиалингвистика в терминах и понятиях» (2018), созданном коллективом 
авторов под руководством проф. Л.Р. Дускаевой и отражающем научные взгляды петербургской школы медиалингвистики.

Структура рецензируемой монографии, а также круг анализируемых в ней лингвистических и собственно медиалингвистических феноменов определяется праксиологическим подходом к медиатексту как к результату анализа социальной реальности и инструменту воздействия на нее в заданном направлении. Инструментально-прикладной, утилитарной природой медиатекста обусловлена постановка вопроса об ассортименте речевых технологий его создания, которые необходимо выявить, типологизировать и описать в дидактических целях как набор речевых навыков, которым можно - и нужно! - обучать и обучаться.

Праксиологический подход, лежащий в основе монографии и базирующийся (применительно к медиалингвистике) на представлении о существовании оптимальных речевых технологий и инструментов для реализации профессионально обусловленной авторской интенции, особенно важен в наше время - время бума гражданской журналистики, или журналистики социальных сетей, основанной на представлении о том, что "каждый сам себе журналист» и что умения пользоваться речью в социальной сфере повседневности вполне достаточно для того, чтобы вещать на многотысячную (а иногда, увы, и многомиллионную) аудиторию.

Двум основным частям монографии («Грамматика субъективности медиаречи» и «Грамматика портретирования окружающего мира в массмедиа») предпослано краткое «Введение в грамматику речевых действий в медиалингвистике» (Л.Р. Дускаева, Т.Ю. Редькина), в котором, в частности, развернуто принципиальое для петербургской школы медиалингвистики положение о том, что в медиатексте как результате лингвопраксиологически обусловленного представления мира наряду с референтной осью представлены также модальная и коммуникативная ось. Данное положение определяет структуру монографии: в первой части рассматриваются речевые средства, формирующие и реализующие модальную и коммуникативную ось медиатекста, во второй - речевые средства, формирующие и реализующие референтную ось.

То, что описание и анализ средств самопрезентации автора предшествуют в монографии описанию и анализу средств презентации («портретирования») окружающего мира, не совсем традиционно для лингвистики текста и литературоведечского анализа. Однако для грамматики медиатекста и медиалингвистики в целом такой подход в изложении представляется логичным, поскольку профессиональная авторская интенция в медиатексте определяет особенности самопрезентации автора, в соответствии с которой реальность не просто отражается, а определенным образом конструируется с помощью речевых средств. В монографии, таким образом, выражено представление о большей, чем это принято считать, значимости автора-говорящего (даже безымянного) в медиатексте.

В разделе «Грамматика субъективности медиаречи» (Т.Ю. Редькина), включающем в себя четыре части («Обозначение позиции субъекта речи», «Профессиональные речевые действия и иллокутивные акты в медиатексте», «Имплицитный и эксплицитный модус в медиатексте», «Прямая и косвенная засвидетельствованность в медиатексте»), очевидна ориентация на функционально-семантические категории коммуникативной грамматики. Предложенное в тексте понимание профессионального речевого действия как «вербализации профессиональной поведенческой реакции говорящего» (с. 47) и соотнесение речевых действий с иллокутивными актами представляется важным в учебно-методическом аспекте, поскольку позволяет раз- 
рабатывать и типологизировать алгоритмы самопрезентации автора и описывать их как объект профессионального обучения.

В тексте раздела «Грамматика субъективности медиаречи» представлены также наблюдения и замечания по поводу конкретных речевых фактов. Так, анализируются причины фиксируемой авторами экспансии модуса «есть ощущение» (с. 74); приводятся интересные примеры того, что авторы называют «модально-диктальной сегментацией» (с. 79); рассматриваются средства выражения не грамматикализованной в русском языке, но семантически важной для медиатекста субкатегории адмиративности (с. 86).

В разделе «Грамматика портретирования окружающего мира в массмедиа» (В.И. Коньков) речевые действия типологизируются на основе функционально-семантических категорий - описания, повествования и рассуждения - в их соотношении с вербализуемой семантикой - предметной, событийной или фактической, что отражено в названиях частей раздела («Мир событий и смежные с ним семантические миры в медийном тексте», «Новость как жанрообразующее речевое действие», «Факультативные речевые действия в новостном дискурсе», «Рассуждение как базовое речевое действие аналитического дискурса», «Факультативные речевые формы в аналитическом дискурсе», «Персонаж в грамматике медиатекста», «Персонаж как элемент картины мира»).

Понятие «речевое действие» является одним из основных для рецензируемой монографии и, как может показаться, в каждой из двух ее частей оно трактуется поразному: в первой части речевые действия соотннесены с иллокутивными актами, во второй - с речевыми жанрами. Данное противоречие, однако, снимается важным замечанием о том, что «при совершении любого речевого действия речь соответствующим образом оформляется» (с. 89): как иллокутивный акт, так и речевой жанр могут реализоваться только с помощью определенных речевых средств. Объединение представленных подходов к пониманию речевого действия позволяет рассматривать триаду «иллокутивный акт - речевое действие - речевой жанр» как ступени реализации профессиональной авторской интенции в медиатексте.

Авторы монографии отмечают, что в ней представлен «анализ специфики употребления языковых средств и поликодовых приемов в воздействующей на массовую аудиторию речи» (с. 28). Успешно справившись с поставленной задачей, авторы также сформулировали определенные проблемы грамматики медиатекста и наметили пути ее дальнейшего развития.

Книга «Грамматика речевых действий в медиалингвистике» является первой частью четырехтомной коллективной монографии, подготовленной кафедрой медиалингвистики Санкт-Петербургского государственного университета. Надеемся, что знакомство с последующими тремя томами - дело ближайшего будущего.

\section{Примечания}

1 Здесь и далее книга «Грамматика речевых действий в медиалингвистике» цитируется с указанием страницы в круглых скобках.

\section{Библиография}

Медиалингвистика в терминах и понятиях: словарь-справлчник / под ред. Л.Р. Дускаевой. М.: ФЛИНТА, 2018. 